\title{
Jugular bulb oxygen saturation correlates with Full Outline of Responsiveness score in severe traumatic brain injury patients
}

This article was published in the following Dove Press journal:

Open Access Emergency Medicine

28 August 2017

Number of times this article has been viewed

\section{Tjokorda Gde Agung \\ Senapathi \\ Made Wiryana \\ Ketut Sinardja \\ Ketut Wibawa Nada \\ Ida Bagus Krisna Jaya \\ Sutawan \\ Christopher Ryalino \\ Aloysius Alphonso}

Department of Anesthesiology and Intensive Care, Udayana University, Sanglah General Hospital, Denpasar, Bali, Indonesia
Correspondence: Christopher Ryalino Department of Anesthesiology and Intensive Care, Udayana University, Sanglah General Hospital, Jl. Diponegoro, Denpasar 80I I4, Bali, Indonesia Email ryalino@gmail.com
Background: Maintaining brain oxygenation status is the main goal of treatment in severe traumatic brain injury (TBI). Jugular venous oxygen saturation $\left(\mathrm{SjvO}_{2}\right)$ monitoring is a technique to estimate global balance between cerebral oxygen supply and its metabolic requirement. Full Outline of Responsiveness (FOUR) score, a new consciousness measurement scoring, is expected to become an alternative for Glasgow Coma Scale (GCS) in evaluating neurologic status of patients with severe traumatic head injury, especially for those under mechanical ventilation.

Methods: A total of 63 patients with severe TBI admitted to emergency department (ED) were included in this study. $\mathrm{SjvO}_{2}$ sampling was taken every 24 hours, until 72 hours after arrival. The assessment of FOUR score was conducted directly after each blood sample for $\mathrm{SjvO}_{2}$ was taken. Spearman's rank correlation was used to determine the correlation between $\mathrm{SjvO}_{2}$ and FOUR score. Regression analysis was used to determine mortality predictors.

Results: From the 63 patients, a weak positive correlation between $\mathrm{SjvO}_{2}$ and FOUR score ( $r=0.246, p=0.052$ ) was found upon admission. Meanwhile, strong and moderate negative correlation values were found in 48 hours $(r=-0.751, p<0.001)$ and 72 hours $(r=-0.49, p=0.002)$ after admission. Both FOUR score $(p<0.001)$ and $\mathrm{SjvO}_{2}(p=0.04)$ were found to be independent mortality predictors in severe TBI.

Conclusion: There was a negative correlation between the value of $\mathrm{SjvO}_{2}$ and FOUR score at 48 and 72 hours after admission. Both $\mathrm{SjvO}_{2}$ and FOUR score are independent mortality predictors in severe TBI.

Keywords: jugular vein, unconsciousness, Full Outline of Responsiveness, mortality predictor

\section{Introduction}

Traumatic brain injury (TBI) is one of the commonest cases in the emergency department (ED). It is one leading cause of mortality in productive age, where the incidence is significantly increased with the increased use of motor vehicles. ${ }^{1,2}$ The efforts to minimize secondary brain injury in TBIs is the key for intervention in neuroanesthesia and intensive care. ${ }^{3}$ The primary goal is to maintain the adequacy of tissue oxygenation. Thus, the ability to do early detection of hypoxia is very essential in critical care, since ischemia and hypoxemia have a vital contribution to the brain damage. ${ }^{1,3}$

Jugular venous oxygen saturation $\left(\mathrm{SjvO}_{2}\right)$ is one of the techniques that can be used to estimate the balance between cerebral oxygen delivery and demand. ${ }^{4-6}$

For $>40$ years, Glasgow Coma Scale (GCS) is the most common method used by clinicians all over the world in assessing consciousness level and neurological condition. Its main features are that it is simple, easy to perform, and does not require any special 
diagnostic tools. ${ }^{7}$ This scale has several limitations such as the interobserver variability and the inability to examine the verbal (V) component in intubated patients. ${ }^{4}$ GCS also fails to explore brain stem reflexes, changes in breathing patterns, and the need for mechanical ventilation, which may explain the severity of unconsciousness. ${ }^{4,5,8}$

Full Outline of Responsiveness (FOUR) score is a new scale for consciousness that was developed by a group of doctors at Mayo Clinic in $2005 .^{4}$ This scale includes the examination of eye, motor, brain stem reflexes, and respiration. ${ }^{4,5}$ The FOUR score provides greater neurological detail than the GCS, recognizes a locked-in syndrome, and is superior to the GCS due to the availability of brainstem reflexes, breathing patterns, and the ability to recognize different stages of herniation. ${ }^{4}$ By expanding the neurological assessment with measurable evaluation, the hope is that FOUR score may provide an innovative and detailed way in assessing level of consciousness in critically ill patients.

\section{Methods}

The aims of this study were to determine the correlation between $\mathrm{SjvO}_{2}$ and FOUR score and to assess whether they act as independent mortality predictors in TBI cases. This study was held from January to March 2017 at ED and intensive care unit (ICU) of Sanglah General Hospital in Denpasar, Indonesia. This study was approved by the research ethics committee of Sanglah General Hospital and Udayana University. All the patients or their guardians have provided written informed consent to be included in this study.

Patients aged from 10 to 70 years with severe traumatic head injury who were admitted to ED were enrolled in this study. Those with cyanotic heart disease, chronic obstructive pulmonary disease, brain stem death upon admission, and contraindication conditions to single-lumen catheter insertion were excluded from the study. $\mathrm{SjvO}_{2}$ sampling was taken from singlelumen catheter in the unilateral side of the brain's pathological process and was taken upon admission, 24 hours, 48 hours, and 72 hours after arrival. After the blood sample was taken, the observer assessed the FOUR score. Patients who were sedated for brain resuscitation purpose were excluded from the study.

Kolmogorov-Smirnov test was used to evaluate data normality. Correlation between $\mathrm{SjvO}_{2}$ and FOUR score was evaluated by Spearman's correlation test. A $p$-value $\leq 0.05$ was considered as statistically significant.

\section{Results}

A total of 63 eligible patients were enrolled in this study. The characteristics of subjects is shown are Table 1 . The median age was 32 years with $44(69.8 \%)$ patients male and the remaining $19(17.9 \%)$ patients female. Out of these 63 patients, $50(79.4 \%)$ were treated with surgical procedure and the others $(20.6 \%)$ were treated conservatively in the ICU. In all, 44 patients (68.8\%) were alive and discharged and the remaining $19(30.2 \%)$ patients died under the treatment in ICU.

Weak positive correlation ( $r=0.246, p=0.052)$ between $\mathrm{SjvO}_{2}$ and FOUR score was found upon patients' arrival. On 24 hours post admission, the correlation between the two was $r=0.481(p=0.082)$. These two correlations were taken as not significant due to their respective $p$-value $(>0.05)$.

Significant negative correlations were found on 48 and 72 hours post admission, with $r=-0.751(p<0.001)$ and $r=-0.49(p=0.002)$, respectively, as shown in Table 2 . These indicate strong correlation at 48 hours and moderate correlation at 72 hours post admission.

In linear regression analysis, we looked for variables with statistically significant mortality predictor. Table 3 shows that $\mathrm{SjvO}_{2}(p=0.04)$ and FOUR score $(p<0.001)$ are statistically significant variables as mortality predictors.

\section{Discussion}

$\mathrm{SjvO}_{2}$ measurement provides information about the balance between supply and demand of brain oxygen status., Unused oxygen in the brain will be delivered to the systemic

Table I Sample characteristics

\begin{tabular}{ll}
\hline Variables & $\mathbf{n}$ \\
\hline Sex, $\mathrm{n}(\%)$ & \\
$\quad$ Male & $44(69.8)$ \\
$\quad$ Female & $19(30.2)$ \\
Age (years), median (IQR) & $32(3 \mathrm{I})$ \\
BMI (kg/m²), median (IQR) & $22.2(14.3)$ \\
Procedure underwent, $\mathrm{n}(\%)$ & \\
$\quad$ Surgical & $50(79.4)$ \\
$\quad$ Conservative/nonsurgical & $13(20.6)$ \\
Patient outcome, $\mathrm{n}(\%)$ & $19(30.2)$ \\
$\quad$ Survivor & $44(69.8)$ \\
$\quad$ Non-survivor &
\end{tabular}

Abbreviations: IQR, interquartile range; BMI, body mass index.

Table 2 Spearman's correlation between $\mathrm{SjvO}_{2}$ and FOUR score

\begin{tabular}{lll}
\hline Time & $\boldsymbol{r}$ & $\boldsymbol{p}$-value \\
\hline Upon arrival & 0.246 & 0.052 \\
24 hours post arrival & $0.48 \mathrm{I}$ & 0.082 \\
48 hours post arrival & $-0.75 \mathrm{I}$ & $<0.00 I^{*}$ \\
72 hours post arrival & -0.49 & $0.002^{*}$ \\
\hline
\end{tabular}

Notes: $r$, Spearman's correlation; *statistically significant.

Abbreviations: $\mathrm{SjvO}_{2}$, jugular venous oxygen saturation; FOUR, Full Outline of Responsiveness. 
Table 3 Regression analysis results to detect mortality predictor

\begin{tabular}{|c|c|c|c|c|c|}
\hline \multirow[t]{2}{*}{ Variables } & \multirow[t]{2}{*}{ B } & \multirow[t]{2}{*}{$p$-value } & \multirow[t]{2}{*}{ OR } & \multicolumn{2}{|c|}{ 95\% Cl for OR } \\
\hline & & & & $\begin{array}{l}\text { Lower } \\
\text { limit }\end{array}$ & $\begin{array}{l}\text { Upper } \\
\text { limit }\end{array}$ \\
\hline Age & -0.18 & 0.412 & 0.982 & $0.94 I$ & 1.025 \\
\hline MAP & -0.17 & 0.641 & 0.984 & 0.918 & 1.054 \\
\hline FOUR score & -0.587 & $<0.000 I^{*}$ & 0.925 & 0.858 & 0.996 \\
\hline $\mathrm{SjrO}_{2}$ & -0.78 & $0.04 *$ & 0.556 & 0.406 & 0.762 \\
\hline
\end{tabular}

Note: *Statistically significant.

Abbreviations: MAP, mean arterial pressure; $\mathrm{OR}$, odds ratio; $\mathrm{Cl}$, confidence interval; FOUR, Full Outline of Responsiveness; $\mathrm{SjvO}_{2}$, jugular venous oxygen saturation.

circulation via internal jugular vein, and therefore, $\mathrm{SjvO}_{2}$ measurement can help to determine the balance between cerebral blood flow (CBF) and cerebral metabolic requirement of oxygen $\left(\mathrm{CMRO}_{2}\right){ }^{3}$

Normal value of $\mathrm{SjvO}_{2}$ is $55-75 \%$. The value $<55 \%$ means patients have inadequate $\mathrm{CBF}$ due to various causes (hyperventilation, reduced cerebral perfusion pressure, and vasospasm) or increased $\mathrm{CMRO}_{2}$. While the value of $>75 \%$ can be caused by hyperemia condition, decreased cerebral metabolism requirement (due to cell death or mitochondrial dysfunction), and microvascular shunting due to oxygen extraction and diffusion disturbance on the damaged brain tissue. These conditions have a poor neurological prognosis.,

FOUR score, a new consciousness scale, has an important advantage for patients treated at ICU as can help evaluate neurological status of intubated patients. Unlike GCS, it does not include verbal component on the examination. ${ }^{4,5,8}$ The FOUR scale includes the examination of eye, motor, brain stem reflexes, and respiration. ${ }^{4,5}$ FOUR score may be a promising method to evaluate consciousness in intubated patients in the intensive care setting.

This study was conducted to determine the correlation between $\mathrm{SjvO}_{2}$ and FOUR score. Weak positive correlation values were found at the admission and 24 hours post admission. However, they were not statistically significant, most likely due to patients being sedated in this period to assist brain resuscitation.

Meanwhile, moderate-to-strong negative correlation values were found at 48 and 72 hours post-arrival period. These results were consistent with the study of Sharf and El-Gebali, which reported a strong positive correlation between $\mathrm{SjvO}_{2}$ and GCS in all cases $(r=0.85$ and $p<0.001)$ and in survived patients $(r=0.74, p<0.001)$. The study also reported a strong negative correlation on 48 and 72 post-arrival periods. These findings show that FOUR score and GCS possess similar features in terms of their relationship with $\mathrm{SjvO}_{2}$.
Gopinath et $\mathrm{al}^{10}$ reported a correlation between desaturation in $\mathrm{SjvO}_{2}$ and final neurological prognosis in brain injury case. Poor final neurological prognosis was obtained in $90 \%$ of patients with recurrent $\mathrm{SjvO}_{2}$ desaturation events. In patients who did not have $\mathrm{SjvO}_{2}$ desaturation events, poor neurological prognosis was found only in $55 \%$ of these patients. Cormio et a ${ }^{11}$ reported that in 450 severe head injury patients treated at the intensive neurosurgical care unit, $25.6 \%$ of patients' with increased $\mathrm{SjvO}_{2}$ got a better outcome (good recovery, moderate disability), $25.6 \%$ recovered with severe disability, and $48.8 \%$ died or turned into vegetative state. The two studies suggest that $\mathrm{SjvO}_{2}$ should be in optimal range, not lower or higher than its normal range.

Both $\mathrm{SjvO}_{2}$ and FOUR score were found to be significant predictors to mortality. Sharf and El-Gebali ${ }^{9}$ also reported that GCS $(p=0.008)$ and $\mathrm{SjvO}_{2}(p<0.001)$ were significant mortality predictors.

The limitation of this study is the sample size that was relatively small. A similar research with a larger sample size can provide more information on the relationship between the two variables.

\section{Conclusion}

$\mathrm{SjvO}_{2}$ is significantly correlated with FOUR score at 48 and 72 hours after patient's arrival. Both $\mathrm{SjvO}_{2}$ and FOUR score are significant mortality predictors. Further research may be needed to get more information about correlation between $\mathrm{SjvO}_{2}$ and FOUR score and to assess their relationship with long-term neurological outcomes such as Extended Glasgow Outcome Scale.

\section{Disclosure}

The authors report no conflicts of interest in this work.

\section{References}

1. Maloney-Wilensky E, Gracias V, Itkin A, et al. Brain tissue oxygen and outcome after severe traumatic brain injury: a systematic review. Crit Care Med. 2009;37(6):2057-2063.

2. Menon DK, Schwab K, Wright DW, et al; Demographics and Clinical Assessment Working Group of the International and Interagency Initiative toward Common Data Elements for Research on Traumatic Brain Injury and Psychological Health. Position statement: definition of traumatic brain injury. Arch Phys Med Rehabil. 2010;91(11):1637-1640.

3. Bhardwaj A, Bhagat H, Grover VK. Jugular venous oximetry. J Neuroanaesthesiol Crit Care. 2015;2:225-231.

4. Wijdicks EF, Bamlet WR, Maramattom BV, Manno EM, McClelland RL. Validation of a new coma scale: The FOUR score. Ann Neurol. 2015;58:585-593.

5. Haddad SH, dan Arabi YM. Critical care management of severe traumatic brain injury in adults. Scand J Trauma Resuc Emerg Med. 2012;20:12. 
6. Schell RM, Cole DJ. Cerebral monitoring: jugular venous oximetry. Anesth Analg. 2000;90(3):559-566.

7. Senapathi TG, Wiryana M, Aribawa IG, Ryalino C. Bispectral index value correlates with Glasgow Coma Scale in traumatic brain injury patients. Open Access Emerg Med. 2017;9:43-46.

8. Jalali R, Rezaei M. A comparison of the Glasgow Coma Scale score with Full Outline of Unresponsiveness Scale to predict patients' traumatic brain injury outcomes in intensive care units. Crit Care Res Pract. 2014;2014:4. Article ID 289803.
9. Sharf MS, El-Gebali MA. Correlation between Glasgow Coma Scale and jugular venous oxygen saturation in severe traumatic brain injury. Egypt J Anesth. 2013;29(3):267-272.

10. Gopinath SP, Robertson CS, Contant CF, et al. Jugular venous desaturation and outcome after head injury. J Neurol Neurosurg Psychiatry. 1994;57(6):717-723.

11. Cormio M, Valadka AB, Robertson CS. Elevated jugular venous oxygen saturation after severe head injury. J Neurosurg. 1999;90(1):9-15.
Open Access Emergency Medicine

\section{Publish your work in this journal}

The Open Access Emergency Medicine is an international, peerreviewed, open access journal publishing original research, reports, editorials, reviews and commentaries on all aspects of emergency medicine. The manuscript management system is completely online and includes a very quick and fair peer-review system, which is all
Dovepress

easy to use. Visit http://www.dovepress.com/testimonials.php to read real quotes from published authors. 